\title{
Chemical profiling, antibacterial and antiparasitic studies of Imperata cylindrica
}

\author{
P.B. Lalthanpuii, Zarzokimi, Kholhring Lalchhandama* \\ Department of Life Sciences, Pachhunga University College, Aizawl, India.
}

\begin{tabular}{|c|c|}
\hline ARTICLE INFO & ABSTRACT \\
\hline Rece & \multirow{5}{*}{$\begin{array}{l}\text { Imperata cylindrica is a common grass with little known medicinal properties. The underground part (comprising } \\
\text { rhizome with roots) is used by the Mizo people for the treatment of microbial and intestinal worm infections. To } \\
\text { understand the chemical and pharmacological properties of the plant part, a methanol extract was prepared in a } \\
\text { Soxhlet apparatus, and the extract was concentrated using a vacuum rotary evaporator. Chemical analysis was done } \\
\text { using gas chromatography-mass spectrometry. Antibacterial activity was tested by Kirby-Bauer test and antiparasitic } \\
\text { activity by survival test in vitro. Fourteen volatile compounds were detected; out of which the most abundant were } \\
n \text {-hexadecanoic acid and (Z)-18-octadec-9-enolide. Some compounds detected including } 2 \text {-methoxy-4-vinylphenol, } \\
6 \text {-methylenebicyclo [3.2.0] hept-3-en-2-one and phenol,2,4-bis (1,1-dimethylethyl) are already known biologically } \\
\text { active compounds. The plant extract was effective against all bacteria tested that included Gram-negative bacteria } \\
\text { such as Pseudomonas aeruginosa and Klebsiella pneumoniae, and a Gram-positive bacterium Bacillus subtilis. It was } \\
\text { also effective against two avian intestinal worms such as the tapeworm Raillietina echinobothrida and the roundworm } \\
\text { Ascaridia galli. These findings reveal the importance of this plant as a source of therapeutic compounds. }\end{array}$} \\
\hline Accepted on: & \\
\hline Available onlin & \\
\hline & \\
\hline $\begin{array}{l}\text { Key words: } \\
\text { Antibacterial activity, } \\
\text { antiparasitic activity, } \\
\text { GC-MS, Imperata cylindrica, } \\
\text { nematode, tapeworm. }\end{array}$ & \\
\hline
\end{tabular}

\section{INTRODUCTION}

A major conundrum in modern medicine and pharmacology is the widespread emergence and evolution of drug resistance among clinically important pathogens and threatens human and veterinary health, food security, and socio-economic conditions (Caniça et al., 2019; Idris et al., 2019). In terms of prevalence and diversity of the infections, bacteria and helminth parasites are at the forefront of this drug resistance dilemma. In fact, multi-drug resistance in bacteria has become a major factor in increased morbidity and mortality worldwide (Bogoch et al., 2019; Jenkins et al., 2017). Anthelmintic resistance is specifically pervasive among helminth parasites of livestock animals. Virtually all veterinary helminths have developed resistance to all available anthelmintic drugs (Brooker, 2018; Moser et al., 2019). It is for these reasons that recent vocal advocates for the pressing need for

${ }^{*}$ Corresponding Author

Kholhring Lalchhandama, Department of Life Sciences, Pachhunga University College, Aizawl,India.E-mail: chhandama@pucollege.edu.in new and alternative medications are supportively justified (Clarke et al., 2018; Willing et al., 2018).

Imperata cylindrica (L.) Räuschel is a perennial and rhizomatous grass in the family Poaceae. It has a thin and lanceolate leaf, and a relatively short stem. The underground parts consist of rhizome and tiny roots that emerge from nodes on the rhizome. The plant is used in different traditional medicines of Southeast Asia for the treatment of various diseases. The flowers and roots have been used as antibacterial, diuretic, skin softening (emollient), antipyretic (febrifuge), salivating (sialagogue), anticoagulant (styptic), and soothing (tonic) agents (Townson, 1991). The roots are specifically used for the treatment ofjaundice, edema, and hematological disorders such as blood urine (hematuria), blood vomit (hematemesis), and nosebleed (epistaxis). Bioactive compounds isolated from the leaves are also shown to have neuro-protective (Yoon et al., 2006) and vasodilative effects (Matsunaga et al., 1994).

To the Mizo people of India and Myanmar, the underground part (rhizome-root extract) is a familiar remedy for bacterial infections and has been used in the treatment of dermal wound, cholera, dysentery, and diarrhea. It is also known to be a good antifungal agent for ringworms and other 
dermatitis (Sawmliana, 2013). The most unique application is for deworming intestinal helminthiasis. The underground parts are crushed, and the juice is directly consumed (Lalthanpuii et al., 2018). The importance of this antiparasitic activity is that, while most anthelmintic compounds or drugs are helminth-specific, the plant extract is equally used for both tapeworm and roundworm species. Therefore, in the light of its medicinal properties, it is worthwhile to perform chemical profiling and test its antibacterial and antiparasitic potentials.

\section{MATERIALS AND METHODS}

\section{Plant material}

Imperata cylindrica was collected from Ngopa (located between $23.8861^{\circ}$ latitude north and $93.2119^{\circ}$ longitude east), a village in Champhai district, Mizoram, India. The specimen was identified at the Botanical Survey of India, Shillong, Meghalaya, and a voucher herbarium (PUC-I-2018-01) is maintained at Pachhunga University College, Aizawl, Mizoram. The underground parts consisting of rhizome and roots were selected and dried in shade at room temperature ranging from $21^{\circ} \mathrm{C}$ to $27^{\circ} \mathrm{C}$.

\section{Preparation of plant extracts}

The dried specimens were pulverized to powder in an electric grinder. Methanol extract was prepared in a 5-liter Soxhlet apparatus. The extract was concentrated by recovering the methanol in a vacuum rotary evaporator (Buchi Rotavapor $\AA$ $\mathrm{R}-215)$. The final plant extract was semi-solid mass and was kept at $4^{\circ} \mathrm{C}$ until further use.

\section{Gas chromatography-mass spectrometry (GC-MS) analysis}

The methanol extract of I. cylindrica was analyzed for chemical identification using the GC-MS system (Thermo Scientific

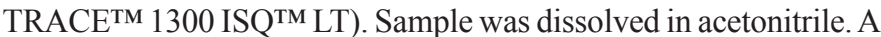
non-polar column used was TR-5MS (260F142P) with a dimension of $30 \mathrm{~m} \times 0.25 \mathrm{~mm} \times 0.25 \mu \mathrm{m}$ and film thickness of $0.25 \mu \mathrm{m}$. The injector port temperature was set at $250^{\circ} \mathrm{C}$. The oven temperature was set at $70^{\circ} \mathrm{C}$ for 2 minutes and gradually raised at an increment of $10^{\circ} \mathrm{C}$ up to $250^{\circ} \mathrm{C}$. Helium was used as the carrier gas and set at a constant flow rate of $1 \mathrm{ml} /$ minute. The sample was injected at a volume of $1 \mu \mathrm{l}$ in the split mode at a splitting ratio of 1:50. The mass spectrometer was run with an electron energy of $70 \mathrm{eV}$ for ionization. Ion source and transfer line temperature were set at $250^{\circ} \mathrm{C}$. Thermo Scientific ${ }^{\mathrm{TM}} \mathrm{Xcalibur}^{\mathrm{TM}}$ software was used for data generation. The total running duration was 55 minutes. Compounds were identified based on retention time, mass spectra, and molecular weight from libraries of Wiley Registry ${ }^{\mathrm{TM}}$ and the National Institute of Standards and Technology database.

\section{Antibacterial activity}

The antibacterial activity of the plant extract was studied using the Kirby-Bauer test. An aerobic Gram-negative bacterium Pseudomonas aeruginosa ATCC $^{\circledR} 10145^{\mathrm{TM}}$ and an anaerobic Gram-negative bacterium Klebsiella pneumoniae ATCC $^{\mathbb{B}}$ $10031^{\mathrm{TM}}$, and an aerobic Gram-positive bacterium Bacillus subtilis ATCC $^{\circledR} 11774^{\mathrm{TM}}$ were used. The bacteria were grown in culture dishes containing Mueller-Hinton agar. The plant extracts were prepared in two concentrations, namely, 10 and $20 \mathrm{mg} / \mathrm{ml}$.
They were impregnated on absorbent disks (Whatman Antibiotic Assay Disks). Negative control contained only the bacteria in agar medium. $20 \mathrm{mg} / \mathrm{ml}$ of ceftriaxone was used as a standard positive antibiotic. The assays were performed in triplicates. The culture dishes were maintained at $37^{\circ} \mathrm{C} \pm 1^{\circ} \mathrm{C}$ in a microbiological incubator for 20 hours. After incubation, the sizes of the inhibition zones were measured.

\section{Antiparasitic test}

Antiparasitic test was performed on two intestinal worms, namely, a tapeworm Raillietina echinobothrida Mégnin, 1880, and a roundworm Ascaridia galli Schrank, 1788. Ethical clearance for the experiment was issued by Pachhunga University College (PUC-IAEC-2016-Z2 of 10/08/2016). The parasites were collected from a freshly sacrificed local fowl, Gallus gallus domesticus Linnaeus, 1857. One hour before the experimental assay, solutions of incremental concentrations such as 5,10, and $20 \mathrm{mg} / \mathrm{ml}$ of the plants extract were prepared in culture plates by dissolving them in $0.9 \%$ neutral phosphate-buffered saline (PBS) supplemented with $1 \%$ dimethylsulfoxide (DMSO). Corresponding concentrations were also prepared for albendazole as standard references. Control experiment consisted only of PBS with DMSO. The parasites were incubated at $37^{\circ} \mathrm{C} \pm 1{ }^{\circ} \mathrm{C}$ in each of the test media. Batches of three worms were selected for each test, and each test was further performed in triplicates. Efficacy was assessed in terms of survival in the culture media. Death was defined as no further motor activity even after stimulation with tepid PBS $\left(45^{\circ} \mathrm{C}\right)$. The times of death were recorded, and data were generated as statistical means \pm standard deviation. Significance of the antiparasitic activity was determined using unpaired Student's $t$-test, and the level of significance was considered when the $p$-value was $<0.05$.

\section{RESULTS}

\section{Extraction and detection of phytocompounds}

The underground parts of I. cylindrica yielded $19.75 \mathrm{~g}$ of methanol extract from $110 \mathrm{~g}$ of the plant sample, i.e., with an extractive value of $17.95 \%$. Standard chemical detection using GC-MS revealed important compounds in the methanol extract of I. cylindrica as shown in Table 1. Compounds were identified from the chromatogram as given in Figure 1. The presence of 14 volatile compounds was established, while compounds with low probabilities were excluded. $n$-Hexadecanoic acid and (Z)-18-octadec-9-enolide were the most abundant at $86.2 \%$ each. In addition, methyl 9-cis, 11 trans-octadecadienoate (36.8), hexadecanoic acid, methyl ester (35.8\%), octadecanoic acid (35.8\%), 6-methylenebicyclo [3.2.0] hept-3-en-2-one (17\%), phenol,2,4-bis (1,1-dimethylethyl) (16.8\%), 2-methoxy-4vinylphenol (16.4\%), and (E)-4-(3-hydroxyprop-1-en-1-yl)-2methoxyphenol (15.8) were the major constituents.

\section{Antibacterial activity}

Ceftriaxone at $20 \mathrm{mg} / \mathrm{ml}$ was effective on the growth inhibition of all bacteria tested, producing inhibition zones of $13 \mathrm{~mm}$ on B. subtilis, $14 \mathrm{~mm}$ on $P$. aeruginosa, and $12 \mathrm{~mm}$ on $K$. pneumonia. The methanol extract of $I$. cylindrica was also effective on all bacteria tested. At 10 and $20 \mathrm{mg} / \mathrm{ml}$, the plant 
Table 1. Chemical compounds identified from the methanol extract of I. cylindrica underground parts using GC-MS.

\begin{tabular}{|c|c|c|c|c|c|}
\hline Sl. no & Retention time & Compound & Formula & $\begin{array}{c}\text { Molecular } \\
\text { weight (Da) }\end{array}$ & Abundance (\%) \\
\hline 1. & 18.80 & 6-Methylenebicyclo [3.2.0] hept-3-en-2-one & $\mathrm{C}_{8} \mathrm{H}_{8} \mathrm{O}$ & 120 & 17.0 \\
\hline 2. & 21.51 & 2-Methoxy-4-vinylphenol & $\mathrm{C}_{9} \mathrm{H}_{10} \mathrm{O}_{2}$ & 150 & 16.4 \\
\hline 3. & 23.79 & Benzaldehyde, 3-(chloroacetoxy)-4-methoxy & $\mathrm{C}_{10} \mathrm{H}_{9} \mathrm{CIO}_{2}$ & 228 & 11.6 \\
\hline 4. & 24.59 & Cyclopropanetetradecanoic acid, 2-octyl, methyl ester & $\mathrm{C}_{26} \mathrm{H}_{50} \mathrm{O}_{2}$ & 394 & 8.6 \\
\hline 5. & 26.61 & Phenol,2,4-bis (1,1-dimethylethyl) & $\mathrm{C}_{14} \mathrm{H}_{22} \mathrm{O}$ & 206 & 16.8 \\
\hline 6. & 31.83 & (E)-4-(3-Hydroxyprop-1-en-1-yl)-2-methoxyphenol & $\mathrm{C}_{10} \mathrm{H}_{12} \mathrm{O}_{3}$ & 180 & 15.8 \\
\hline 7. & 35.64 & Hexadecanoic acid, methyl ester & $\mathrm{C}_{17} \mathrm{H}_{34} \mathrm{O}_{2}$ & 270 & 35.8 \\
\hline 8. & 36.44 & n-Hexadecanoic acid & $\mathrm{C}_{16} \mathrm{H}_{32} \mathrm{O}_{2}$ & 256 & 86.2 \\
\hline 9. & 36.93 & $\begin{array}{l}\text { L-Methionyl-D-glutaminyl-D-methionyl-L-asparaginyl-L-lysyl-L- } \\
\text { valyl-L-leucyl-D- } \alpha \text {-aspartyl-L-serine }\end{array}$ & $\mathrm{C}_{43} \mathrm{H}_{76} \mathrm{~N}_{12} \mathrm{O}_{15} \mathrm{~S}_{21}$ & 1064 & 11.8 \\
\hline 10. & 38.85 & Methyl 9-cis, 11 trans-octadecadienoate & $\mathrm{C}_{19} \mathrm{H}_{34} \mathrm{O}_{2}$ & 294 & 36.8 \\
\hline 11. & 39.67 & (Z)-18-Octadec-9-enolide & $\mathrm{C}_{18} \mathrm{H}_{32} \mathrm{O}_{2}$ & 280 & 86.2 \\
\hline 12. & 40.10 & Octadecanoic acid & $\mathrm{C}_{18} \mathrm{H}_{36} \mathrm{O}_{2}$ & 284 & 35.8 \\
\hline 13. & 42.90 & Octadecanoic acid, ethyl ester & $\mathrm{C}_{25} \mathrm{H}_{42} \mathrm{O}_{2}$ & 374 & 11.4 \\
\hline 14. & 48.07 & $\begin{array}{l}\text { 2,4,6,8,10-Tetradecapentanoic acid, 9a-(acetyloxy)- } \\
\text { 1a,1b,4,4a,5,7a,7b,8,9a-decahydro-4a,7b-dihydroxy-3- } \\
\text { (hydroxymethyl)-1, 1,6,8-tetramethyl-5-oxo-1H-cyclopropa[3,4] } \\
\text { benz[1,2-e] azulen-9yl ester, [1aR-(1aa,1ba,4aa,7aa,7ba,8a,9a,9aa)]- }\end{array}$ & $\mathrm{C}_{36} \mathrm{H}_{46} \mathrm{O}_{8}$ & 606 & 10.4 \\
\hline
\end{tabular}

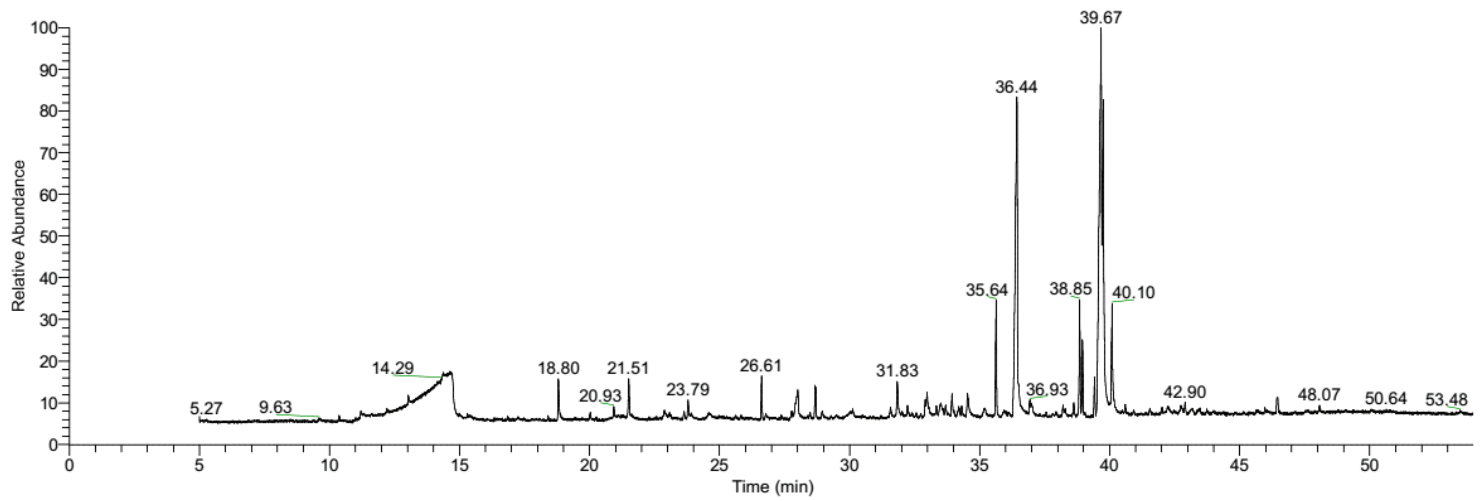

Figure 1. GC-MS chromatogram of the methanol extract of $I$. cylindrica underground parts.

extract produced inhibition zones of 9 and $10 \mathrm{~mm}$ on $B$. subtilis, 7 and $8 \mathrm{~mm}$ on $P$. aeruginosa, and 6 and $8 \mathrm{~mm}$ on $K$. pneumonia, respectively. Thus, the relative susceptibility of the bacteria species for the plant extract was in an order $B$. subtilis $>$. aeruginosa $>$ K. pneumonia.

\section{Antiparasitic activity}

The methanol extract of $I$. cylindrica was effective against both the tapeworms and roundworms. As given in Table 2, control tapeworms survived up to $74.03 \pm 1.89$ hours. Albendazole was highly effective and killed $R$. echinobothrida in $14.99 \pm 0.43,12.07 \pm 0.49$, and $8.99 \pm 0.45$ hours at the concentrations of 5,10 , and $20 \mathrm{mg} / \mathrm{ml}$, respectively. At similar concentrations, I. cylindrica extract took $60.69 \pm 4.81,48.19$ \pm 4.89 , and $30.58 \pm 3.15$ hours to completely kill the worms. A. galli survived much longer, up to $187.01 \pm 6.77$ hours in the plant extract (Table 3). In albendazole, they survived for $56.94 \pm 1.76,18.01 \pm 2.73$, and $15.97 \pm 1.99$ hours at 5, 10, and $20 \mathrm{mg} / \mathrm{ml}$, respectively. Imperata cylindrica extract was effective only at 10 and $20 \mathrm{mg} / \mathrm{ml}$.

\section{DISCUSSION}

GC-MS analysis of the underground parts of I. cylindrica revealed the presence of interesting volatile compounds. Of the different compounds detected from I. cylindrica, some are already known to have important biological effects. For example, 2-methoxy-4-vinylphenol has been isolated from pine (Pinus species) needles and is demonstrated to have potent anticarcinogenic activity by specifically blocking the hyper-phosphorylation of retinoblastoma protein in vitro (Jeong and Jeong, 2010). It also promotes anti-inflammatory response suppression of nuclear factor kappa-light-chain-enhancer of activated B cells (NF- $\kappa \mathrm{B})$ and mitogen-activated protein kinase (MAPK) activation, and acetylation of histone H3 (Jeong et al., 2011). 6-Methylenebicyclo [3.2.0] hept-3-en-2-one is also isolated from Allium tuberosum and is shown to be an important defensive molecule for the plant against infection with the root-knot nematode, Meloidogyne species (Huang et al., 2016). Phenol,2,4-bis (1,1-dimethylethyl) is reported from avocado (Persea americana) and acts as an effective antifungal compound against fungal pathogens such as Aspergillus and Phytophthora cinnamomi (Rangel-Sánchez et al., 2014). 
Table 2. Efficacy of the methanol extract of I. cylindrica underground parts on the tapeworm, R. echinobothrida. $(n=6)$.

\begin{tabular}{lcccc}
\hline Treatment & Dose (mg/ml) & $\begin{array}{c}\text { Survival time (hour) } \\
\text { in mean } \pm \text { standard } \\
\text { deviation (SD) }\end{array}$ & $\boldsymbol{t}$ value & $\boldsymbol{t}$ critical value \\
\hline Control & 0 & $74.03 \pm 1.89$ & $\mathrm{NA}$ & $\mathrm{NA}$ \\
Albendazole & 20 & $08.99 \pm 0.45^{*}$ & 81.85 & 2.23 \\
& 10 & $12.07 \pm 0.49^{*}$ & 77.66 & 2.23 \\
& 5 & $14.99 \pm 0.43^{*}$ & 74.53 & 2.23 \\
I. cylindrica & 20 & $30.58 \pm 3.15^{*}$ & 28.99 & 2.23 \\
& 10 & $48.19 \pm 4.89^{*}$ & 12.06 & 2.23 \\
& 5 & $60.69 \pm 4.81^{*}$ & 06.32 & 2.23 \\
\hline
\end{tabular}

*Significantly different at $p<0.05$.

Table 3. Efficacy of the methanol extract of I. cylindrica underground parts on the roundworm, A. galli $(n=6)$.

\begin{tabular}{lcccc}
\hline Treatment & Dose $(\mathbf{m g} / \mathbf{m l})$ & $\begin{array}{c}\text { Survival time (hour) } \\
\text { in mean } \pm \text { SD }\end{array}$ & $\boldsymbol{t}$ value & $\boldsymbol{t}$ critical value \\
\hline Control & 0 & $187.01 \pm 6.77$ & & \\
Albendazole & 20 & $015.97 \pm 1.99^{*}$ & 28.87 & 4.30 \\
& 10 & $018.01 \pm 2.73^{*}$ & 56.69 & 2.23 \\
& 5 & $056.94 \pm 1.76^{*}$ & 45.53 & 2.23 \\
I. cylindrica & 20 & $102.07 \pm 2.84^{*}$ & 28.34 & 2.23 \\
& 10 & $140.68 \pm 5.19^{*}$ & 13.40 & 2.23 \\
& 5 & $183.46 \pm 3.67$ & 01.13 & 2.31 \\
\hline
\end{tabular}

*Significantly different at $p<0.05$.

Imperata cylindrica underground parts are traditionally familiar to the Mizo people as anti-infectious agents. They are used as broad-spectrum antimicrobials and anthelmintics for different microbial and helminth infections. Our study shows that the methanol extract is quite effective against pathogenic bacteria, such as $B$. subtilis, $P$. aeruginosa, and $K$. pneumonia. It was most effective on $B$. subtilis on which its efficacy was comparable to that of tetracycline. As secondary metabolites of plants are a good source of antimicrobial agents (Chandra et al., 2017), as such further investigation of this plant is a compelling task to fully explore its pharmacological potential on microbial pathogens of medical importance.

Validating the traditional application, this study also shows that I. cylindrica is an effective antiparasitic agent. There are serious concerns in the management of parasitic infections such as drug resistance and adverse effects. These factors raise the need for novel drugs (Clarke et al., 2018). In this context, the plant extract in the present study is remarkable in that it is effective on both the tapeworms and roundworms. This is important because tapeworms and roundworms have contrasting structural and physiological properties (Abongwa et al., 2017).

Tapeworms are soft-bodied helminths without the digestive system so that absorption of nutrients or drugs is direct through the body surface called tegument (Taman and Azab, 2014). Whereas roundworms are hard-bodied helminths covered with tough cuticle and nutrients or drugs are ingested into a digestive tract. The course of drug action is therefore prolonged and requires complex interaction with motor and signaling proteins (Greenberg, 2014). For these reasons, drugs are usually specific for each group of helminths. The effectiveness of $I$. cylindrica extract against both tapeworms and roundworms as demonstrated in this study is, therefore, an evidence that the plant is a promising source of novel anthelmintic molecules, which exert broad-spectrum activity.

\section{CONCLUSION}

GC-MS analysis revealed that the methanol extract of I. cylindrica underground part contains important volatile compounds, some of which are known to be pharmacologically bioactive compounds. This is not an exhaustive analysis and the plant is likely to contain more interesting compounds. Validating the medicinal use as antibacterial and antiparasitic agents, the plant extract was effective against three bacteria including Gram-negative bacteria such as $P$. aeruginosa and $K$. pneumoniae, and a Gram-positive bacterium $B$. subtilis. It was an interesting observation that the plant extract was also effective against intestinal parasites such as the tapeworm $R$ echinobothrida and the roundworm $A$. galli.

\section{AUTHORS' CONTRIBUTION STATEMENT}

\begin{tabular}{lccc}
\hline Contribution & P.B. Lalthanpuii & Zarzokimi & K. Lalchhandama \\
\hline Concept and Design & Yes & - & Yes \\
Experiment & Yes & Yes & - \\
Data acquisition & Yes & Yes & - \\
Data analysis & - & - & Yes \\
Manuscript writing & - & - & Yes \\
Manuscript editing/review & Yes & Yes & Yes \\
\hline
\end{tabular}

\section{ACKNOWLEDGMENT}

The research is supported by the Science and Engineering Research Board (SERB), Government of India, through research project no. EMR/2016/004053 of 23/03/2017. PBL is a Senior Research Fellow under the project. GC-MS facility was provided by the Directorate of Forensic Science Laboratory, Government of Mizoram.

\section{CONFLICT OF INTEREST}

None declared.

\section{REFERENCES}

Abongwa M, Martin RJ, Robertson AP. A brief review on the mode of action of antinematodal drugs. Acta Vet, 2017; 67:137-52.

Bogoch II, Utzinger J, Lo NC, Andrews JR. Antibacterial mass drug administration for child mortality reduction: Opportunities, concerns, and possible next steps. PLoS Negl Trop Dis, 2019; 13:e0007315.

Brooker SJ. Soil-transmitted helminth treatment: multiple-drug regimens. Lancet Infect Dis, 2018; 18:698-9.

Caniça M, Manageiro V, Abriouel H, Moran-Gilad J, Franz CM. Antibiotic resistance in foodborne bacteria. Trends Food Sci Technol, 2019; $84: 41-4$.

Chandra H, Bishnoi P, Yadav A, Patni B, Mishra A, Nautiyal A. Antimicrobial resistance and the alternative resources with special emphasis on plant-based antimicrobials - a review. Plants, 2017; 6:16(1-11).

Clarke NE, Doi SA, Wangdi K, Chen Y, Clements AC, Nery SV. Efficacy of anthelminthic drugs and drug combinations against soiltransmitted helminths: a systematic review and network meta-analysis. Clin Infect Dis, 2018; 68:96-105.

Greenberg RM. Ion channels and drug transporters as targets for anthelmintics. Curr Clin Microb Rep, 2014; 1:51-60. 
Huang YH, Mao ZC, Xie BY. Chinese leek (Allium tuberosum Rottler ex Sprengel) reduced disease symptom caused by root-knot nematode. J Integr Agric, 2016; 15:364-72.

Idris OA, Wintola OA, Afolayan AJ. Helminthiases; prevalence, transmission, host-parasite interactions, resistance to common synthetic drugs and treatment. Heliyon, 2019; 5:e01161.

Jenkins HE, Yuen CM, Rodriguez CA, Nathavitharana RR, McLaughlin MM, Donald P, et al. Mortality in children diagnosed with tuberculosis: a systematic review and meta-analysis. Lancet Infect Dis, $2017 ; 17: 285-95$.

Jeong JB, Jeong HJ. 2-Methoxy-4-vinylphenol can induce cell cycle arrest by blocking the hyper-phosphorylation of retinoblastoma protein in benzo [a] pyrene-treated NIH3T3 cells. Biochem Biophys Res Commun, 2010; 400:752-7.

Jeong JB, Hong SC, Jeong HJ, Koo JS. Anti-inflammatory effect of 2-methoxy-4-vinylphenol via the suppression of NF- $\kappa \mathrm{B}$ and MAPK activation, and acetylation of histone H3. Arch Pharmacal Res, 2011; 34:2109-16.

Lalthanpuii PB, Zarzokimi, Lalchhandama K. Imperata cylindrica: a noxious weed of pharmacological potentials. In Lalchhandama $\mathrm{K}$ (ed.). Advances in engineering research: perspective and trends in the development of science education and research. Atlantis Press, Paris, France, pp 173-7, 2018.

Matsunaga K, Shibuya M, Ohizumi Y. Graminone B, a novel lignan with vasodilative activity from Imperata cylindrica. J Nat Prod, 1994; 57:1734-6.

Moser W, Schindler C, Keiser J. Drug combinations against soiltransmitted helminth infections. Adv Parasit, 2019; 103:91-115.
Rangel-Sánchez G, Castro-Mercado E, García-Pineda E. Avocado roots treated with salicylic acid produce phenol-2, 4-bis (1, 1-dimethylethyl), a compound with antifungal activity. J Plant Physiol, 2014; 171:189-98.

Sawmliana M. The Book of Mizoram Plants. P. Zakhuma, Aizawl, India, p 143, 2013.

Taman A, Azab M. Present-day anthelmintics and perspectives on future new targets. Parasitol Res, 2014; 113:2425-33.

Townson JK. Imperata cylindrica and its control. Weed Abstr, 1991; 40:457-68.

Willing BP, Pepin DM, Marcolla CS, Forgie AJ, Diether NE, Bourrie BC. Bacterial resistance to antibiotic alternatives: a wolf in sheep's clothing? Anim Front, 2018; 8:39-47.

Yoon JS, Lee MK, Sung SH, Kim YC. Neuroprotective 2-(2-phenylethyl) chromones of Imperata cylindrica. J Nat Prod, 2006; 69:290-1

How to cite this article:

Lalthanpuii PB, Zarzokimi Z, Lalchhandama K. Chemical profiling, antibacterial and antiparasitic studies of Imperata cylindrica. J Appl Pharm Sci, 2019; 9(12):117-121. 